\title{
JUOZAS VALČIUKAS
}

Mykolo Romerio universitetas, Lietuva

Mykolas Romeris University, Lithuania

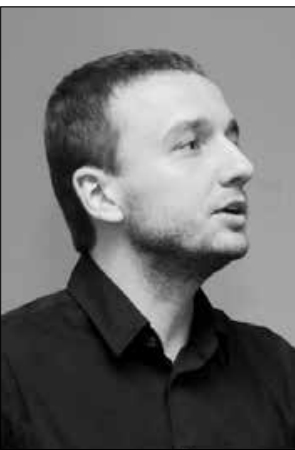

\section{TEISÉ I AKADEMINĘ LAISVĘ IR JOS SAMPRATA}

\section{Right to Academic Freedom and its Concept}

\begin{abstract}
SUMMARY
There is no democratic society without free science, research and the university as such. The right to academic freedom is a fundamental democratic right. Although it is guaranteed by national as well as international laws, today this fundamental right faces unprecedented challenges and is increasingly under pressure in a growing number of countries. This paper turns attention to the very essence of academic freedom. The aim is to look at the term of academic freedom, to examine the concept of a right to academic freedom trying to identify its content, interrelated dimensions, relationship with the other rights. The right to academic freedom as an individual and as an institutional right is analysed taking into account the actual legal practice of international courts. In addition to this, this paper pays particular attention to the right of academics to participate in public debates expressing ideas outside the campus, what needs to be treated as a part of the right to academic freedom.
\end{abstract}

\section{SANTRAUKA}

Demokratinè visuomenė nę̨sivaizduojama be laisvo mokslo, tyrimų ir universiteto. Teisė i akademinę laisvę yra fundamentali demokratinè teisè. Nors ji užtikrinama nacionalinių ir tarptautinių teisės aktų, šiandien ši fundamentali teise susiduria su beprecedenčiais iššǔkiais ir kai kuriose valstybèse patiria vis didejjantį spaudimą. Šis straipsnis kviečia pažvelgti i pačią akademinės laisvės esmę. Straipsnio tikslas yra pažvelgti ị akademinès laisvès sąvoką, išanalizuoti teisẻs į akademinę laisvę sampratą bandant išgryninti jos turini, tarpusavyje susijusias dimensijas ir santykị su kitomis teisèmis. Teisé i akademinę laisvę kaip asmeninè ir institucinė teisè nagrinėjama remiantis naujausia tarptautinių teismų praktika. Be to, itin daug dėmesio straipsnyje skiriama akademikų teisei dalyvauti viešosiose diskusijose už universiteto ribų, kas laikytina sudedamąja teisés į akademinę laisvę dalimi.

RAKTAŽODŽlAI: akademinè laisvė, teisė į akademinę laisvę, saviraiškos laisvė, Konstitucija, universitetas. KEY WORDS: academic freedom, right to academic freedom, freedom of expression, Constitution, University. 


\section{IVADAS}

Akademinès laisvės, universitetų autonomijos ir apskritai saviraiškos laisvès vertybėms šiandien kyla nemažai iššūkiu, galinčių iš esmès pakeisti universitetų vaidmení, itaką visuomenei ir jos ateičiai. Štai, pavyzdžiui, Respublikos ¡kūrimo šimtmečio išvakarèse prestižinio Turkijos Bogazici universiteto bendruomenè, kurioje ne vieną dešimtmeti sugyvena religinè ir liberalioji mintis, keletą mėnesių taikiais protestais reiškiamas nepasitenkinimas Prezidento Recepo Tayyipo Erdogano paskirtu naujuoju rektoriumi dèl grèsmès akademinei laisvei $^{1}$. Reaguojant $i$ akademinès bendruomenès protestus, čia ne tik pasitelkta policija, bet ir priimti vykdomosios valdžios isakai ikurti universitete naujus teisès ir komunikacijos fakultetus. Honk Konge, remiantis Kinijos valdžios išleistais naujais įstatymais (nacionalinio saugumo isstatymu ir kt.), atsisakoma politiškai nepatogiu dėstytoju paslaugu, i universitetų valdymo organus integruojami lojalūs centrinès valdžios linijai asmenys, konstruojamos naujos raudonosios linijos diskutuojant jautriais Kinijai klausimais ${ }^{2}$. Tuo tarpu Indijoje valstybès finansuojami universitetai, ju profesoriai ir administracija prieš rengdami tarptau- tinius virtualius renginius (konferencijas, forumus ir pan.), kuriuose būtų diskutuojama aiškiai su Indijos vidaus reikalais susijusiais klausimais, privalo gauti Indijos užsienio reikalų ministerijos leidimą rengti tokius ir panašius renginius ${ }^{3}$. Vengrijoje po Centrinės Europos Universiteto "išprašymo“ iš šalies prasidejo universitetu restruktūrizavimo politikos igyvendinimo tarpsnis, kuris vadinamas universitetu "privatizavimo eros" pradžia ${ }^{4}$. Visi šie ir kiti šios dienos iššūkiai skatina sugrižti prie diskusijos apie tai, kas turima galvoje kalbant apie teisę $\mathfrak{i}$ akademinę laisvę.

Straipsnyje siekiama išanalizuoti teisẻs į akademinę laisvę sampratą nagrinejjant, pirmiausia, klausima, kas apskritai yra akademinè laisvè. Antra, straipsnyje aiškinamasi, koks yra teisès i akademinę laisvę turinys, koks jos santykis su kitomis konstitucinès reikšmès teisèmis. Šie klausimai atskleidžiami žvelgiant iz istoriškai svarbius dokumentus, šios dienos teisini reguliavimą, teismu praktika, mokslinę doktriną. Siekiant užsibrèžtu tikslų, straipsnyje naudojamasi mokslinès literatūros analizès, teismu praktikos analizès, apibendrinimo, istoriniu ir lyginamuoju metodais.

\section{KAS YRA AKADEMINĖ LAISVĖ?}

Jeigu reikètų apibūdinti akademinès laisvès sąvoka, dažnas pasakytu, kad tai reiškia universiteto desstytojų akademinëje erdvëje turimas teises ir laisves. Vis dèlto tai nèra visapusiško akademinès laisvès apibūdinimo pavyzdys. Štai
$1915 \mathrm{~m}$. JAV universitetu profesorių asociacijos deklaracija akademinę laisvę apibūdina kaip moksliniu tyrimu ir ju rezultatų viešinimo laisvès, dèstymo laisvès ir saviraiškos už universiteto ribu laisvę. Šis apibrěžimas, kad ir plačiai 
nušviečia akademinès laisvės vertybę, tačiau neapima, pavyzdžiui, studentu saviraiškos ir gyvenimo universitete laisvès ir kitų klausimu. Ne veltui toje pačioje Amerikoje vienas po kito XX a. viduryje prasidejjo studentu judèjimai, reikalaujantys akademinès laisvès ir saviraiškos galimybių.

Akademinès laisvès istorija yra kur kas ankstesnè negu pats akademinès laisvès terminas (Nelson 2010: 1). Sąvoka pirmą kartą pavartota XIX a. pradžios Vokietijoje, kur mokslo ir dèstymo laisvėms buvo suteiktas konstitucinis statusas itvirtinus jas dar $1848 \mathrm{~m}$. Konstitucijoje (17 str.). Tai vadinama moderniuju Vakarų akademinės laisvės sąvokos vartojimo pradžios momentu (Williams 2016: 33). Tačiau paties reiškinio istorija yra kur kas platesnè ir sudètingesnè. Ivairiais laikotarpiais vyravęs požiūris i universitetą ir jo autonomija, akademinès bendruomenès narių saviraiškos, minties ir sąžinès laisvę bei jos ribas nulèmé akademinès laisvės sampratos pokyčius. Akademinès laisvès ribu nustatymas priklausė nuo daugelio faktoriu ir galëjo būti veikiamas skirtingų subjektụ. Tarp jų politinis elitas, bažnyčia, valstybè, universitetu administracija ar steigejaai, dèstytoju korpusas ar studentu asociacijos suvaidino tam tikrą vaidmeni skirtingais akademinès laisvès formavimosi tarpsniais.

Prisimintinas Sokrato minties ir žodžio, dėstymo laisvès, kviečiant jauną žmogų mąstyti argumentais, persekiojimas (Stone 2015: 197). Laisvos minties Atėnų mieste filosofas buvo apkaltintas už savo idejjas, i̇sitikinimus ir mokymą bei nuteistas mirties bausme, dèl ko daugelis Sokratą vèliau vadino pirmuoju žodžio ir minties laisvės kankiniu (ten pat: 210). Vèliau Viduramžių universitetų visiška priklausomybẻ nuo bažnyčios kontrolès, kuri neretai virsdavo tam tikra cenzūra, kaip antai $1546 \mathrm{~m}$. paskelbtas uždraustų knygų sąrašas (Index Librorum Prohibitorum). 1933 m. Vokietijos valdžios politika skirti universitetu rektorius ir, pavyzdžiui, Berlyno universiteto rektoriaus parinkimu nulemti netrukus universitete pristatytų 25 naujų studijų dalyku, skirtu itvirtinti rasinès politikos prioritetus, atsiradimą (Grundmann ir Stehr 2012: 77). Arba Didžiosios Britanijos tarpukariu (profesoriaus Karlo Wichmano atvejis ir kiti) ir Amerikos XX a. viduryje vykdytas marksizmo, komunizmo idejjų mokslininku stebẻjimas ir atleidinejjimas iš darbo remiantis "lojalumo programomis", ko kulminacija laikytina ekonomikos profesoriaus Paulo Sweezy atleidimo dèl paskaitu turinio byla Amerikoje (Post: 2012: 69-72). Be to, studentu grupių siekis akademinès laisvės sąvoką pakeisti akademinio teisingumo terminu arba reikalavimas sukurti universitetą kaip saugią erdvę, kurioje būtu galima atsiriboti nuo perdèm jautriu studijų dalykų, temu, taigi ir priversti dèstytojus užsiimti savicenzūra (Nelson 2010: 185-195).

Baigtinio akademinès laisvès apibrèžimo nėra nei mokslinèje doktrinoje, nei teismu praktikoje. Tai paaiškinama tuo, $\mathrm{kad}$ su visuomenès transformacijomis kinta ir akademinès laisvès samprata. Aišku, kad akademiné laisve yra demokratinès valstybės konstitucinè vertybė, susijusi su mokslinio pažinimo procesu, žiniu paieškomis, tyrinejimu laisve ir ideju išraiškos laisve. Kalbant apie akademinę laisvę visada turima galvoje aukštojo mokslo istaiga - universitetas. 
O universitetas demokratinëje valstybëje laikytinas intelektualine konkrečios valstybès ir visuomenès sąžine (Williams 2016: 40). Kiek akademinès laisvès turès akademinès bendruomenès nariai: mokslininkai, dėstytojai, studentai, kiek institucinė aukštujų mokyklų autonomija harmoningai sąveikaus su jos narių akademine laisve, kiek valstybės įsikišimas i universiteto bei atskiru akademinès bendruomenės narių minties bei jos išraiškos laisvę bus retas, kaip chirurgo intervencija, tiek laisva akademinè bendruomené savo ekspertinemis žiniomis galès prisidèti prie viešosios nuomonès formavimo, viešoji nuomonè bus kritiškesnè ir efektyviau prižiūrinti valdžios darbus, o tai reikš geras demokratijos sąlygas.

\section{TEISÉ I AKADEMINĘ LAISVĘ IR JOS SANTYKIS SU KITOMIS TEISĖMIS}

Teisè i akademinę laisvę daugelyje pasaulio valstybiu nèra eksplicitiškai itvirtinta Konstitucijoje. Dažniausiai jos statusas, turinys atsiskleidžia analizuojant teisę i akademinę laisvę kitų teisių požiūriu. Teisè i i isitikinimų ir jų raiškos laisvę, teisè į minties, sąžinès laisvę, teise i ž žodžio laisvę, teisè i̇ privatų gyvenimą ir kt. yra glaudžiai susijusios su akademinès laisvès principu. Ryšys su kitomis teisèmis ir pats akademinès laisvès principo turinys byla po bylos aiškinamas teismų nagrinejjant implicitinį teisinị reguliavimą.

Vienas iš retų tiesioginio teisès ị akademinę laisvę įtvirtinimo nacionalinèje teisëje pavyzdžių yra Graikijos valstybės Konstitucija (16 str.), kurioje expressis verbis vartojama akademinès laisvės sąvoka. Lietuvos Respublikoje, kaip ir daugelyje kitu valstybiu, Konstitucijos tekste nèra tiesiogiai išskirtos teisès ị akademinę laisvę. Lietuvos Konstitucinis Teismas ne viename iš savo nutarimu konstatavo, kad Konstitucijos 42 str. 1 d. yra įtvirtintas akademinès laisvès principas, kad akademinès laisvès principas yra neatsiejamas nuo įsitikinimų ir jų išraiškos laisvès ir kad šis principas išreiškia sieki apginti nuo išorès įtakos mokslininkų ir dèstytojų mokslinės minties ir jos išraiškos laisvę.

Kalbant apie tarptautinius dokumentus, tai eksplicitiškai teisè i akademinę laisvę įtvirtinta Europos Sąungos Pagrindinių teisių chartijoje (13 str.). Visuotinëje žmogaus teisių deklaracijoje arba Europos Žmogaus teisių ir pagrindiniu laisviu konvencijoje tiesiogiai itvirtinto akademinès laisvès principo nèra, tačiau jis yra sudètinis šiu tarptautinès teisès dokumentų turinio komponentas. Europos Žmogaus Teisių teismo sprendimu analizè rodo, kad ši teisè yra tiesiogiai susijusi su Konvencijos 10 str. teise i saviraiškos laisvę

Teisè i akademinę laisvę dažnai laikoma išvestine teise iš platesnès apimties teisès į saviraiškos laisvę. Štai Strasbūro teisme nagrinejjant bylą dèl Turkijos universiteto dėstytojo pasisakymų televizijoje, kurioje dalyvavimui nepritarusi universiteto valdžia sumažino dèstytojui atlyginima, EŽTT teige šiuo atveju nagrinejjantis Konvencijos 10 straipsnio galimą pažeidimą dèl akademiko teisès i saviraiškos laisvę. Pasak EŽTT, šis Konvencijos straipsnis gina, be kita ko, ir forma, kuria idejos perduodamos. Dès- 
tytojas, dalyvaudamas televizijos laidoje, realizavo savo teisę išreikšti idejjas ir požiūrì kaip akademikas. Taigi EŽTT pripažino, kad byla lietė akademinę laisvę, kuri garantuoja akademiko saviraiškos laisvę, laisvę dalintis informacija ir atliktuc tyrimu rezultatais. Byloje konstatuota, kad Turkija pažeidè akademiko saviraiškos laisvę, kurią gina Konvencijos 10 straipsnis $^{6}$. Iš tikruju akademinė laisvé šioje byloje laikyta teisès i saviraiškos laisvę dalimi. Pritartina pozicijai, kad reikalingas tam tikras testas, kuriuo remiantis EŽTT galètų atsakyti, ar ir kokiu mastu konkrečiai teisè i akademinę laisvę, o ne tik saviraiškos laisvè kaip jos „,skètinè koncepcija”, buvo pažeista ${ }^{7}$.

Teise i minties laisvę apima pedagoginès minties laisvę, kuri tiesiogiai susijusi su teise į akademinę laisvę. Pedagoginès, mokslinès minties laisvè, kaip akademinès laisvès principo sudètinè dalis, turètų būti analizuojama skirstant ją į dvi dalis. Pirma, pedagoginès, mokslinès minties laisvè suprantama kaip mąstymo procesas, neišreikštas į išorę. Ši laisvė yra absoliuti. Antra, pedagoginès, mokslinès minties laisvè, kuri išreikšta visuomenejje, perteikta kitam asmeniui. Ši pedagoginès, mokslinès minties laisvė yra santykinè, taigi gali būti ribojama.

Teisès i privatumą santykio su akademinès laisvės principu tema aktualiau- siai atsiskleidė EŽTT byloje, kurioje nagrinètas klausimas dèl filmavimo kameru irengimo universiteto auditorijose teisètumo. Juodkalnijos dėstytojai apskundè universiteto veiksmus izrengiant filmavimo kameras ir tam tikrą laiką filmuojant universiteto erdvèse, kuriose vyko paskaitos. Dėstytojai teigè, kad ju teisè į privatu gyvenimą dèl tokio filmavimo ir atitinkamo duomenu rinkimo buvo pažeista. Iš tikruju EŽTT pripažino Konvencijos 8 str. pažeidimą ${ }^{8}$, tačiau šioje vietoje svarbesnis kitas klausimas. Ar akademinejje aplinkoje vykstantis dėstymo ir studiju procesas neturètų būti vertinamas per akademinès laisvès argumento prizmę? Galutinis sprendimas, kad buvo pažeista teisé i privatumą, nepasikeistu. Tačiau šiuo atveju privatumas reiškia ne tiek teisę i privatu gyvenimą darbo vietoje, kiek teisę i privatumą desstymo ir studiju proceso metu. Kitaip tariant, akademinis gyvenimas paskaitose reikalingas tam tikro privatumo, tai yra i jij neturi kištis nei universiteto administracija, nei tuo labiau išorinès valstybinès institucijos. Mokslinè veikla, studiju metu atliekama veikla ar dèstymo veikla, kuri apima pedagoginès, mokslinès minties igyvendinima, dèstomo dalyko turinį ir jo kitą kartą subtilu isisavinimo procesa, gali ir turi likti po tam tikru privatumo šydu.

\section{TEISĖS | AKADEMINĘ LAISVĘ TURINYS}

Teisès i akademinę laisvę turinys, vidinè struktūra geriausiai atsiskleidžia nagrinejjant ją keliais lygmenimis. Pirma, teisè į akademinę laisvę suprantama kaip asmeninè teisè. Ji atspindi atskiru akademinès bendruomenès narių teises ir laisves. Antra, teisè $\mathfrak{i}$ akademinę laisvę analizuojama kaip institucinè teisè. Ji susijusi su universiteto ir jo padaliniu teisine padètimi, universiteto autonomijos klausimais ir pan. Kaip pabrèžiama UNESCO rekomendacijose dèl aukštojo 
mokslo dėstytoju personalo statuso, universitetinè autonomija yra institucinè akademinès laisvès forma ir būtinybè siekiant garantuoti aukštojo mokslo personalo ir padalinių funkcijų igyvendinimą . Trečia, teisė i akademinę laisvę susijusi ir su valstybès pareiga gerbti akademinę laisvę ir imtis priemonių užtikrinant bei ginant ją.

Teise i akademinę laisvę, kaip asmeninè teisè, siejasi su dėstytoju, mokslinin$\mathrm{ku}$, tyrèjų, studentų teisèmis. Tai apima teisę studijuoti, teisę dèstyti, teisę tyrinèti, teisę $\mathfrak{i}$ informaciją, teisę publikuoti savo tyrimų rezultatus, teisę pasisakyti ir užsiimti veiklomis ne universitete ir pan. EŽTT dažniausiai nagrinėtos akademinès laisvès bylos siejasi su dėstytoju, tyrëjų teise dalyvauti viešose diskusijose ir pasisakyti už universiteto ribų. Ši teisè yra didesnès rizikos, nes ją gali pažeisti tiek pats universitetas, tiek valstybės valdžia ar išorinės suinteresuotos grupès. Pavyzdžiui, EŽTT byloje Mustafa Erdogan ir kiti prieš Turkija nagrinėtas klausimas dèl konstitucinès teisės profesoriaus išspausdinto straipsnio, kuriame jis kritikavo Konstitucinį teismą prièmus sprendimą panaikinti politinę partiją ir kèlè teisèju profesionalumo, kompetencijos klausimą. Turkijos teismai tokius pasisakymus ir jų turini prilygino teisëjų garbès ir orumo izžeidimui ir skyrè straipsnio autoriui baudą. Šiuo atveju EŽTT nagrinejjo klausimą dèl galimo teisès profesoriaus saviraiškos laisvės pažeidimo. Akademinè laisvè, kaip saviraiškos laisvès dalis, pasak EŽTT, apima ne tik tyrimus ir dėstymą universitete, bet ir akademiku laisvę reikšti savo požiūrị bei nuomonę atliktų tyrimų, turimų ekspertinių žinių ir kompetencijų srityse už universiteto ribų. Tai apima, be kita ko, ir viešą vei- kiančių valstybės institucijų kritikavimą bei sprendimų vertinimą. Šioje byloje atskiroje triju teisèju, tarp jų ir Egidijaus Kūrio, nuomonèje atkreiptas dèmesys i reikšmingą mokslinio diskurso informacinę funkciją skirtą praplèsti ekspertinèmis žiniomis, tyrimų rezultatais visuomeninį diskursa, ypač kas liečia viešuosius valstybès reikalus.

Teisè $i$ akademinę laisvę, kaip institucinè teisè, susijusi su universiteto autonomijos samprata. Universitetas turi autonomiją dèl klausimu, kurie susiję su universiteto vidaus tvarka, pavyzdžiui, priimant i pareigas dėstytojus, tyrëjus, priimant studentus i studijas ir pan. Be to, institucinę akademinès laisvès dimensiją galima pažeisti, jei nacionalinès valstybès priimti teisinès bazès pakeitimai varžo apskritai galimybes universitetui veikti. Štai 2020 m. pabaigoje Europos Sajungos Teisingumo teismas (toliau - ESTT) prièmè sprendimą dèl Vengrijos nustatytų universitetų akreditavimo taisyklių užsienio universitetams. Nauji Vengrijos teisiniai instrumentai numatè užsienio valstybių universitetams, siekiantiems veikti Vengrijoje, reikalavimą pasirašyti tarptautini susitarimą tarp Vengrijos valstybès ir universitetą akredituojančios šalies. Pasirašymo klausimas, kaip ir susitarimo turinio klausimas, liktų Vengrijos valdžios diskrecijoje. Be to, pakoreguotas Vengrijos aukštojo mokslo istatymas numatė reikalavimą aukštojo mokslo institucijai, kuri siekia veikti Vengrijoje, ne tik būti įsteigtai užsienio valstybejje, bet toje valstybeje ir realiai teikti švietimo paslaugas. Siekdama pateisinti suvaržymus, Vengrijos vyriausybe aiškino siekianti apsaugoti viešają tvarką. Pasak ESTT, Vengrijos nustatyti suvaržymai pažeidè ne tik tokias fundamentalias ES teises, 
kaip teisę îsisteigti, teisę î laisvą paslaugu judejimą bendrijos šalyse, bet ir universitetų teisę $i$ akademinę laisvę ${ }^{10}$. Nustatytais pakeitimais buvo sudaryta galimybė valdžiai vienašališkai įsikišti i aukštojo mokslo institucijos veikimo klausimus. Pirmą kartą ne tik ESTT, bet ir EŽTT sprendimų istorijoje akademinès laisvès byla buvo susieta teismo labiau su akademinès laisvès principo institucine dimensija negu su universiteto dėstytojų teise i saviraiškos laisvę.

Akademinės laisvės būklę galima vertinti ją analizuojant ne tik per asmeninès ar institucinès teisès prizmę, bet ir kaip valstybès pareigą gerbti, užtikrinti ir ginti ją. Valstybè per savo institucijas bei pareigūnus turi tokią pareigą. To nesilaikymas gali reikšti akademinès laisvès pažeidimą. Valstybė turi nesikišti ir nesukelti papildomų varžymų akademinei laisvei tiek asmeniniu, tiek ir instituciniu lygmeniu. Šioje vietoje nesigilinant i daugeli aspektu, kaip aktyviais ir pasyviais veiksmais valstybe turètų veikti, svarbu paminèti itin aktualų nacionalinio saugumo ir akademinès laisvès santykio iššūkị. Viena iš šešiolikos akademinei laisvei aktualių grèsmių ịvardijami varžymai, kurie neretai pateisinami nacionalinio saugumo intereso pagrindu (Nelson, 2010: 54). Kaip tokie varžymai pasireiškia? Pavyzdžiui, siekiant užkardyti terorizmo grèsmę, stebimi bibliotekos resursu naudojimosi duomenys, tam tikri užsienio dèstytojai netenka teisès pasisakyti konferencijose, kai kuriems vietos tyrejams apribojama laisvè ir pan. (Chatterjje, Maira 2014: 6). Atkreiptinas dèmesys ì specifini akademinès laisvès pažeidima, kada apribojama galimybè komunikuoti su kitų šalių mokslininkais. Tokie atvejai iliustruoja, kaip svarbu kiekvienu atveju išanalizuoti, kaip derinamos nacionalinio saugumo akademinès laisvès vertybès.

\section{IŠVADOS}

Akademinè laisvè yra neatskiriama demokratinès visuomenès gyvavimo dalis. Pats akademinès laisvès terminas pirmą kartą sutinkamas XIX a. Vokietijoje. Tačiau pačios laisvès istorija turi daug gilesnes istorines šaknis, siekiančias Sokrato laikus ir pan. Istoriškai akademinè laisvè išgyveno daugelį ribojimų, kuriuos inicijavo ịvairūs subjektai, pavyzdžiui, politinio režimo veikẻjai, bažnyčia, valstybè, universiteto administracija, universiteto finansiniai rèmëjai, dèstytoju korpusas ar studentu grupès. Šiandien akademinès laisvès samprata yra pakankamai išplètota ir yra teisinès apsaugos objektas. Nepaisant to, kaip rodo kai kurių valsty- bių aktuali praktika, tai nepaneigia galimybès imtis ribojimų ir pažeidimų.

Teisiniame reguliavime teisè $i$ akademinę laisvę dažniausiai įtvirtinta implicitiškai. Tokiu būdu ji dažnai suprantama kaip sudètinè tam tikros kitos teisès dalis. Pavyzdžiui, teisè i akademinę laisvę dažnai gretinama su teise ì saviraiškos, žodžio laisvę, minties laisvę, sąžinès laisvę ir pan.

Pastebimi per paskutinius penkerius metus tarptautinių teismų žingsniai, žengiami plètojant akademinès laisvès koncepciją. Kad teismai akademinę laisvę vertintų ne per skètines kitų teisių sampratas, reikia dar vieno žingsnio, tai yra 
teisinio testo itvirtinimo teismu praktikoje identifikuojant teisès ì akademinę laisvę pažeidimus.

Teisès ì akademinę laisvę turinys atsiskleidžia analizuojant ją kaip asmeninę

\section{Literatūra}

Chatterjje Piya, Maira Sunaina (eds.). 2014. The Imperial University: Academic Repression and Scholarly Dissent. Minneapolis: University of Minnesota Press.

Grundmann Reiner, Stehr Nico. 2012. The Power of Scientific Knowledge from Research to Public Policy. Cambridge: Cambridge University Press.

Nelson Cary. 2010. No University is an Island: saving academic freedom. New York: New York University Press.

\section{Nuorodos}

${ }^{1}$ https://www.al-monitor.com/pulse/originals/ 2021/02/turkey-students-detained-bogazici-melih-bulu-akp-kaaba-lgbt.amp.html?skip Wem= $1 \& \_$twitter_impression=true\&skipWem $=1 \&$ twitter_impression=true

2 https://www.universityworldnews.com/post. php?story $=20210204110051872$

${ }^{3} \mathrm{https} / / / \mathrm{m}$.thewire.in/article/education/universities-now-need-govt-approval-for-online-international-events-on-indias-internal-matters/amp

${ }^{4}$ https://verfassungsblog.de/loyalty-opportunismand-fear/

${ }^{5}$ Pavyzdžiui, Europos Žmogaus Teisių teismo 2014 m. sprendimas byloje Hasan Yazici prieš Turkiją, taip pat Europos Žmogaus Teisių teismo $2014 \mathrm{~m}$. sprendimas byloje Mustafa Erdogan prieš Turkija. akademinès bendruomenès narių teisę, kaip institucinę teisę, kuri susijusi su universiteto autonomija, taip pat kaip valstybės pareiga gerbti, užtikrinti ir ginti akademinę laisvę.

Post Robert C. 2012. Democracy, Expertise, Academic Freedom and a First Amendment Jurisprudence for the Modern State. New Haven and London: Yale University Press.

Stone I. F. 2015. The Trial of Socrates. London: Head of Zeus.

Williams Joanna. 2016. Academic Freedom in an age of Conformity: Confronting the Fear of Knowledge. Hampshire: Palgrave.

${ }^{6}$ Europos Žmogaus Teisių teismo 2018 m. sprendimas byloje Kula prieš Turkiją.

7 Europos Žmogaus Teisių teismo 2014 m. sprendimo byloje Mustafa Erdogan prieš Turkija atskiroji teisejų Sajo, Vučinič ir Kūrio nuomonè.

${ }^{8}$ Europos Žmogaus Teisių teismo 2017 m. sprendimas byloje Antovič ir Mirkovič prieš Juodkalniją.

${ }^{9} \mathrm{http}$ ://portal.unesco.org/en/ev.php-URL_ID= 13144\&URL_DO=DO_TOPIC\&URL_SECTION= 201.html

10 http://curia.europa.eu/juris/document/document.jsf?docid $=232082 \&$ mode $=$ req\&pageIndex $=$ $1 \&$ dir $=\&$ occ $=$ first\&part=1\&text=\&doclang=EN\& cid $=5941926$ 